\title{
Ly6h Regulates Trafficking of Alpha7 Nicotinic Acetylcholine Receptors and Nicotine-Induced Potentiation of Glutamatergic Signaling
}

\author{
Clare A. Puddifoot, ${ }^{1 *}$ Meilin Wu, ${ }^{1 *}$ Rou-Jia Sung, ${ }^{1}$ and William J. Joiner ${ }^{1,2,3,4}$ \\ ${ }^{1}$ Department of Pharmacology, ${ }^{2}$ Biomedical Sciences Graduate Program, ${ }^{3}$ Neurosciences Graduate Program, and ${ }^{4}$ Center for Circadian Biology, University \\ of California San Diego, La Jolla, California 92093-0636
}

$\alpha 7$ nAChRs are expressed widely throughout the brain, where they are important for synaptic signaling, gene transcription, and plastic changes that regulate sensory processing, cognition, and neural responses to chronic nicotine exposure. However, the mechanisms by which $\alpha 7 \mathrm{nAChRs}$ are regulated are poorly understood. Here we show that trafficking of $\alpha 7$-subunits is controlled by endogenous membrane-associated prototoxins in the Ly6 family. In particular, we find that Ly6h reduces cell-surface expression and calcium signaling by $\alpha 7 \mathrm{nAChRs}$. We detect Ly6h in several rat brain regions, including the hippocampus, where we find it is both necessary and sufficient to limit the magnitude of $\alpha 7$-mediated currents. Consistent with such a regulatory function, knockdown of Ly6h in rat hippocampal pyramidal neurons enhances nicotine-induced potentiation of glutamatergic mEPSC amplitude, which is known to be mediated by $\alpha 7$ signaling. Collectively our data suggest a novel cellular role for Ly6 proteins in regulating nAChRs, which may be relevant to plastic changes in the nervous system including rewiring of glutamatergic circuitry during nicotine addiction.

Key words: acetylcholine receptor; Ly6; modulation; nicotine; plasticity; trafficking

\section{Introduction}

nAChRs regulate presynaptic neurotransmitter release (McGehee et al., 1995) and postsynaptic membrane potential, calciumdependent intracellular signaling, and gene transcription (Chang and Berg, 2001; Dajas-Bailador and Wonnacott, 2004). nAChRs contribute to various physiological functions of the nervous system, such as learning and memory, attention, the sleep/wake cycle, and critical periods for developmental plasticity (Levin et al., 1998; Léna et al., 2004; Thiel and Fink, 2008; Morishita et al., 2010; Wu et al., 2014). The importance of these receptors is also highlighted by their dysregulation, which is thought to contribute to pathophysiological conditions including nicotine addiction,

Received Aug. 29, 2014; revised Jan. 2, 2015; accepted Jan. 14, 2015.

Author contributions: C.A.P., M.W., and W.J.J. designed research; C.A.P., M.W., and R.-J.S. performed research; M.W. contributed unpublished reagents/analytic tools; C.A.P., M.W., and R.-J.S. analyzed data; C.A.P., M.W., and W.J.J. wrote the paper.

This work was supported by National Institutes of Health Grant NS072431, Whitehall Foundation Grant WF20110560, and a Pharma Foundation Research Starter Grant to W.J.J., R.-J.S. was supported by the University of California, San Diego, Research Fellowship in Biological Psychiatry (5 T32 MH018399-27) and the Tobacco-Related Disease Research Program Postdoctoral fellowship (23FT-0118). We thank Henry Lester for generously providing $\alpha 7$, YFP- $\alpha 7$, and Ric3 expression plasmids. We also thank Palmer Taylor for providing the TN-XXL plasmid and for discussions about our work. We thank John Yamauchi and Kimberly Gomez for assistance with the calcium flux assay, Joan Brown for providing rat tissue for primary neuron cultures, and Laura Dozier and Gentry Patrick for help establishing hippocampal cultures. We are also grateful to James Robinson for feedback about this manuscript and to Cian $0^{\prime}$ Donnell for advice about mEPSC analysis.

${ }^{*}$ C.A.P. and M.W. contributed equally to this work.

The authors declare no competing financial interests.

Correspondence should be addressed to Dr. William Joiner, 9500 Gilman Drive, BSB 3082, La Jolla, CA $92093-$ 0636. E-mail: wjoiner@ucsd.edu.

DOI:10.1523/JNEUROSCI.3630-14.2015

Copyright $\odot 2015$ the authors $\quad 0270-6474 / 15 / 353420-11 \$ 15.00 / 0$ schizophrenia, Parkinson's disease, and Alzheimer's disease (for review, see Dani and Bertrand, 2007; Miwa et al., 2011).

Cognitive roles for $\mathrm{nAChRs}$ are particularly important in the hippocampus, where calcium influx through homomeric $\alpha 7$ nAChRs is thought to facilitate glutamatergic synaptogenesis and synaptic transmission, establishment of pyramidal neuron circuitry, and long-term potentiation (Yamazaki et al., 2006; Gu et al., 2012; Lozada et al., 2012b). However, little is known about the mechanisms that regulate $\mathrm{nAChR}$ function in these contexts. Several groups have shown that nAChRs can be modulated by auxiliary proteins belonging to the Ly6 family (Ibañez-Tallon et al., 2002; Miwa et al., 2006; Tekinay et al., 2009; Wu et al., 2014). However, these functions have largely been limited to changes in ACh affinity or desensitization kinetics of heteromeric nAChRs, which exhibit relatively low calcium permeability. Furthermore, these studies have yet to establish the roles of Ly6 proteins in functionally relevant structures such as the hippocampus.

Ly6 proteins share certain structural features, including four to five disulfide bonds and a characteristic "three-finger" fold seen for each protein for which crystallographic or NMR structure has been obtained (Lyukmanova et al., 2011). This fold is thought to be important for recognition and modulation of $\alpha 4 \beta 2$ nAChRs by Ly6 proteins. However, snake venom $\alpha$-neurotoxins such as $\alpha$-bungarotoxin and $\alpha$-cobratoxin share the same fold and antagonize $\alpha 7 \mathrm{nAChRs}$ with high affinity (Dellisanti et al., 2007), thus suggesting that regulatory targets of Ly6 proteins may extend to calcium-permeable nAChRs.

Here we confirm this hypothesis and show that a major function of some Ly6 proteins, including previously uncharacterized 
Table 1. Ly6 EST subcloning

\begin{tabular}{lcll}
\hline & EST clone ID & Cut sites & pcDNA3 sites \\
\hline Lynx2 & 6313510 & Sacll(blunt)/Not1 & EcoRV/Not1 \\
Ly6h & 1245940 & EcoR1/Not1 & EcoR1/Not1 \\
Ly6c1 & 4221342 & Sal1(blunt)/Not1 & EcoRV/Not1 \\
Ly6e & 3490293 & Sal1(blunt)/Not1 & EcoRV/Not1 \\
Ly6a & 3486025 & EcoR1/Not1 & EcoR1/Not1 \\
Ly6g6d & 40130265 & Spe1(blunt)/Not1 & EcoRV/Not1 \\
\hline
\end{tabular}

Table 2. Ly6 cloning primer sequences and subcloning sites

\begin{tabular}{clll}
\hline & Forward & Reverse & Restriction sites \\
\hline Ly6c2 & $5^{\prime}$-GGTACCATGGACAGTACT- & 5'-TCTAGAGGAAGGACCATCA- & Kpn1/Xba1 \\
& CACGCTACAAAG-3' & GAGCAAGGTC-3' & \\
Ly6g6e & $5^{\prime}$-GGTACCCCAGACTGCTGAGCTG- & 5'-TCTAGACATCTGTGCAGGT- & Kpn1/Xba1 \\
& TACC-3' & GTTTTCA-3' & \\
Lypd2 & $5^{\prime}$-GGTACCGGCAGGCCTGAGT- & 5'-TCTAGAGATGTCAGGGA- & Kpn1/Xba1 \\
& GAGGA-3' & CAAGGGAGTG-3' & \\
\hline
\end{tabular}

Table 3. Ly6 MYC tagging primers

\begin{tabular}{|c|c|c|}
\hline & Forward & Reverse \\
\hline Lynx2-Myc & $\begin{array}{l}\text { 5'-CTGCAACACCCCTATCGAGCA- } \\
\text { GAAGC-3' }\end{array}$ & $\begin{array}{l}\text { 5' -GGGCCTCGGCCCATTGCACA- } \\
\text { GATC-3' }\end{array}$ \\
\hline Ly6h-Myc & $\begin{array}{l}\text { 5' -CTGCTGCGAGAAAGATATCGAGCA- } \\
\text { GAAGC-3' }\end{array}$ & $\begin{array}{l}\text { 5'-GCGACCGATGCCCCGTTGCACA- } \\
\text { GATC-3' }\end{array}$ \\
\hline Ly6e-Myc & $\begin{array}{l}\text { 5'-CTGCTGCCAAAGCTCCATCGAGCA- } \\
\text { GAAGC-3' }\end{array}$ & $\begin{array}{l}\text { 5'-GGCCAGCTGCGCTGAAGTTG- } \\
\text { CATTTATC-3' }\end{array}$ \\
\hline Ly6g6d-Myc & $\begin{array}{l}\text { 5' -GAAAAACTGCTGTTTTGGAGATATC- } \\
\text { GAGCAGAAGC-3' }\end{array}$ & $\begin{array}{l}5^{\prime} \text {-GAGCTTGCCACGGCGCTGTTG- } \\
\text { CACAGATC- } 3^{\prime}\end{array}$ \\
\hline Ly6g6e-Мyc & $\begin{array}{l}\text { 5' - GCTGTGAGCAGGACATCGAGCA- } \\
\text { GAAGC-3' }\end{array}$ & $\begin{array}{l}\text { 5'-GGCTGTGAGGCGGCAGCGTTG- } \\
\text { CACAGATC-3' }\end{array}$ \\
\hline Lypd2-Myc & $\begin{array}{l}\text { 5'-CCTGCTGCAATTCTGACATCGAGCA- } \\
\text { GAAGC-3' }\end{array}$ & $\begin{array}{l}\text { 5'-GGGTGCCCCATCCACGTTGCACA- } \\
\text { GATC-3' }\end{array}$ \\
\hline Ly6a-Myc & $\begin{array}{l}5^{\prime} \text {-CCTGTTGCCAGGAAGACATCGAGCA- } \\
\text { GAAGC- } 3^{\prime}\end{array}$ & $\begin{array}{l}\text { 5'-CCTCCATTGGGAACTGCTACGTT } \\
\text { GCACAGATC- } 3^{\prime}\end{array}$ \\
\hline
\end{tabular}

as well as characterized molecules, is to regulate levels of $\alpha 7$ nAChRs at the cell surface. This trafficking function thus allows some Ly6 proteins to serve as a gain control for calcium-mediated cholinergic signaling. We find that one of these molecules, Ly6h, is found in most hippocampal pyramidal neurons and is both necessary and sufficient to limit $\alpha 7$-mediated currents. Ly6h also limits nicotine-mediated postsynaptic potentiation of glutamatergic signaling in pyramidal neurons, most likely through antagonism of $\alpha 7$. These findings define a novel pathway by which Ly6 proteins modulate cholinergic signaling in processes thought to underlie synaptic plasticity, cognition, and nicotine addiction.

\section{Materials and Methods}

Molecular biology. Mouse Ly6 genes were cloned from expressed sequence tags (ESTs; Open Biosystems) indicated in Table 1 or from adult CD1 mouse brain cDNA using PCR primers indicated in Table 2. ESTs and PCR products were subcloned into the mammalian expression vector pcDNA3 using the restriction sites listed in Tables 1 and 2. The MYC epitope was inserted immediately upstream of the predicted glycosylphosphatidylinositol-anchoring site of each Ly6 molecule by PCR stitching as previously described (Wu et al., 2014) using the primers listed in Table 3. Ly6h shRNA and scrambled controls were generated by annealing the following sense and antisense oligos and subcloning them into pSilencer-5.1 H1-Retro between the BamH1 and HindIII sites: Ly6h-shRNA-S: 5'-GATCCCCGGACTGCTGCGAGAAAGATTTTTC AAGAGAAAATCTTTCTCGCAGCAGTCCTTTTTTGGAAA-3'; Ly6hshRNA-AS: 5 '-AGCTTTCCAAAAAAGGACTGCTGCGAGAAAGATT TTCTCTTGAAAAATCTTTCTCGCAGCAGTCCGGG-3'; SCR-S: 5' -G
ATCCCCACTAACGAGTAGTCGGTTGGATTCAAGAGATCCAACCG ACTACTCGTTAGTTTTTTTGGAAA-3';SCR-AS:5' -AGCTTTCCAAA AAAACTAACGAGTAGTCGGTTGGATCTCTTGAATCCAACCGACT ACTCGTTAGTGGG-3'.

For Ly6 sequence alignments, signal peptides and amino acid C-terminal to GPI attachment sites were omitted from translation products of cloned Ly6 cDNAs, as predicted using algorithms available at http://mendel.imp.ac.at/gpi/gpi_server.html (Eisenhaber et al., 1999), http://www.cbs.dtu.dk/services/SignalP/ (Petersen et al., 2011), and http://gpi.unibe.ch/. The resulting mature proteins were aligned using ClustalW2 (Larkin et al., 2007).

FRET-based measurements of $n A C h R$ activity. Measurements of $\alpha 7$ $\mathrm{nAChR}$ activity were performed as previously described (Yamauchi et al., 2011) with the following alterations: HEKtsa cells were transiently transfected with mouse $\alpha 7$-pcDNA3 and hRic3-pcDNA3 (gifts from $\mathrm{H}$. Lester) plus TN-XXL (a gift from P. Taylor) supplemented with either Ly6-pcDNA3 or pcDNA3 alone at a ratio of 1:1:2:10. Cells were preincubated for $30 \mathrm{~min}$ in ACSF containing the following (in $\mathrm{mM}$ ): 121 $\mathrm{NaCl}, 5 \mathrm{KCl}, 26 \mathrm{NaHCO}_{3}, 1.2 \mathrm{NaH}_{2} \mathrm{PO}_{4} \mathrm{H}_{2} \mathrm{O}, 10$ glucose, 5 HEPES, 2.4 $\mathrm{Ca}^{2+}$, and $1.3 \mathrm{Mg}^{2+}, \mathrm{pH} 7.4$, and supplemented with $10 \mu \mathrm{M} \mathrm{N}-(5-$ chloro-2,4-dimethoxyphenyl)- $N^{\prime}$ (5-methyl-3-isoxazolyl)-urea (PNU)120596 to block receptor desensitization. For each experiment individual concentration-response curves were fit to the Hill equation to calculate $\mathrm{EC}_{50}$ or $\mathrm{IC}_{50}$ values as well as maximal responses. For bar graphs these values were normalized in each experiment to values obtained for $\alpha 7$ $\mathrm{nAChR}$ alone. Maximum response was calculated as the bottom of the generated concentration-response curve subtracted from the top and normalized to $\alpha 7 \mathrm{nAChR}$ alone. One-way ANOVA repeated-measures analysis with Dunnett's multiple-comparison post-test was used for statistical analysis.

Cell culture and transfection. HEKtsa cells were maintained at $37^{\circ} \mathrm{C}$ and $5 \% \mathrm{CO}_{2}$ in culture medium consisting of $10 \%$ fetal bovine serum (Omega), 1\% penicillin/streptomycin (Mediatech), and 1\% L-glutamine (Sigma) in low-glucose DMEM with $2 \mathrm{mM}$ L-glutamine (Mediatech). Cells were grown to $50-80 \%$ confluence for transfection with X-tremeGENE HP reagent (Roche) at a 2:1 ratio of transfection reagent to DNA in OptiMEM (Life Technologies). Transfection mixture was removed $24 \mathrm{~h}$ after transfection and replaced with normal growth medium. Cells were lysed $48 \mathrm{~h}$ after transfection in SDS lysis buffer containing the following (in mM): 10 Tris, pH 7.5; $100 \mathrm{NaCl} 5$ EDTA; 1\% Triton X-100; and 0.05\% SDS with Complete protease inhibitor (Roche). Primary hippocampal neuronal cultures were prepared as previously described (Puddifoot et al., 2012) from P2 Sprague Dawley rats of either sex (Harlan Laboratories). Briefly, dissociated hippocampal cells were plated on $11 \mathrm{~mm}$ polyD-lysine-coated glass coverslips and maintained in growth media containing Neurobasal A and B-27 (Life Technologies), Pen-Strep (Mediatech), $1 \mathrm{~mm}$ glutamine, and $1 \%$ FBS. Cultures were incubated at $37^{\circ} \mathrm{C}$ in humidified 5\% $\mathrm{CO}_{2}$. At $4 \mathrm{DIV}, 9.6 \mu \mathrm{M}$ cytosine-D-arabinofuranoside hydrochloride (Ara C; Sigma) was added to prevent proliferation of glial cells. Neurons were transfected with plasmids $(1.5-2.5 \mu \mathrm{g} / \mathrm{ml}$ total for overexpression and knockdown, respectively). pBOB GFP was cotransfected with additional plasmids at a ratio of either 1:5 (overexpression) or 1:2 (shRNA knockdown). Cells were transfected in supplemented NBA growth media (above) without serum using Lipofectamine 2000 (Life Technologies).

Cell-surface biotinylation. Forty-eight hours after transfection, HEKtsa cells were rinsed twice in ice-cold PBS, $\mathrm{pH}$ 8.0, and incubated in PBS, $\mathrm{pH}$ 8.0 , with $0.3 \mathrm{mg} / \mathrm{ml} \mathrm{NHS}$-biotin (Pierce) for $45 \mathrm{~min}$ on ice. The biotinylation reaction was quenched by two 5 min incubations in quenching buffer containing the following (in $\mathrm{mm}$ ): 50 Tris base, $\mathrm{pH} 7.4 ; 275 \mathrm{NaCl}$; $6 \mathrm{KCl}$; and $2 \mathrm{CaCl}_{2}$. Labeled cells were rinsed once in PBS before lysis in lysis buffer containing the following (in mM): $250 \mathrm{NaCl}$; 50 Tris $\mathrm{HCl}, \mathrm{pH}$ 7.4; 5 EDTA; $0.5 \%$, and Triton X-100 with Complete protease inhibitor (Roche).

Immunoprecipitation and immunoblotting. Five hundred micrograms of total cell lysate was incubated in a total volume of $1 \mathrm{ml}$ RIPA buffer containing the following (in $\mathrm{mm}$ ): $150 \mathrm{NaCl} ; 25$ HEPES, pH $7.5 ; 1 \%$ Triton X-100; 0.1\% SDS; and 1\% sodium deoxycholate with Complete protease inhibitor (Roche) and rabbit anti-GFP antibody (Life Technol- 


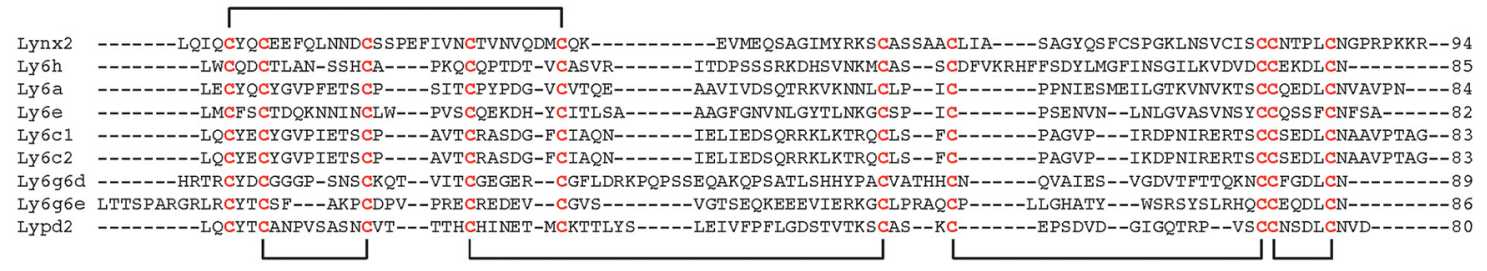

Figure 1. Ly6 proteins have a conserved cysteine-rich motif. Amino acid alignments were performed using ClustalW2. Previously annotated Ly6 proteins were included to improve alignment fidelity; however, only the nine Ly6 proteins used in this study are shown here. Predicted signal sequences and C-terminal cleaved domains were removed before analysis, with amino acid numbering adjusted accordingly. Predicted disulfide bonds are indicated by the black brackets.

ogies) or streptavidin-conjugated agarose beads (Pierce) overnight at $4^{\circ} \mathrm{C}$ on a rotating platform. The following day, protein G-conjugated magnetic beads (NEB) were added to total $\alpha 7$-immunoprecipitated samples and incubated at $4^{\circ} \mathrm{C}$ for $2-5 \mathrm{~h}$. Protein $\mathrm{G}$ magnetic beads and streptavidin-agarose beads were washed three times in a $1 \mathrm{ml}$ volume of RIPA buffer and resuspended in $2 \times$ LDS sample buffer (Life Technologies). Western blot analyses of cell lysates and coimmunoprecipitation complexes were performed as previously described (Wu et al., 2008). For $10 \%$ input conditions, $50 \mu \mathrm{g}$ of protein was loaded per lane. Proteins were detected using the following antibodies: rabbit anti-GFP (Life Technologies), mouse anti-Myc (Santa Cruz Biotechnology), mouse antiLy6h (Novus Biologicals), and mouse anti-actin (Millipore EMD).

Immunostaining. Primary hippocampal neurons were plated onto glass coverslips coated with poly-D-lysine and cultured for $7 \mathrm{~d}$ before fixation. Immunostaining was performed as previously described (Puddifoot et al., 2012) using Ly6h antibody (1:400; Novus Biologicals), Myc antibody (1:500; Santa Cruz Biotechnology), and GFP antibody (1:2000; Life Technologies). Briefly, cells were rinsed in ice-cold PBS and fixed in $4 \%$ formaldehyde/PBS for $10 \mathrm{~min}$ at room temperature. Cells were blocked for $1 \mathrm{~h}$ at room temperature in 10\% normal goat serum (Life Technologies) and then sequentially incubated in primary antibodies (overnight at $4^{\circ}$ in anti-Ly6h antibody, $2 \mathrm{~h}$ at room temperature in antiGFP or anti-Myc antibody). Labeled cells were washed three times in ice-cold PBS and incubated in secondary antibody for $1 \mathrm{~h}$ at room temperature and DAPI (Sigma) for $1 \mathrm{~min}$ at room temperature, then mounted on glass slides in Vectashield (Vector Laboratories). Fluorescently conjugated secondary antibodies used were Alexa Fluor goat antimouse 488 and Alexa Fluor goat anti-rabbit 568 (Life Technologies). Cells were imaged on a Leica SP5 confocal microscope at $40 \times$ magnification.

Electrophysiology. Recordings of agonist-evoked whole-cell currents were made $48-72 \mathrm{~h}$ after transfection. Coverslips containing hippocampal neurons were transferred into a recording chamber containing ACSF containing the following (in mM): $140 \mathrm{NaCl}, 3 \mathrm{KCl}, 25 \mathrm{HEPES}, 1 \mathrm{CaCl}_{2}$, 20 glucose, 0.0003 tetrodotoxin, and 0.0003 atropine. For drug application by bath perfusion, the external solution was applied adjacent to the patched cell at a constant flow rate of $4 \mathrm{ml} / \mathrm{min}$ at room temperature $\left(22-25^{\circ} \mathrm{C}\right)$ using a ValveLink8.2 Pinch Valve Perfusion System (Automate). Cells were visualized using a $40 \times$ water-immersion lens (Olympus). For whole-cell recordings data were acquired using a Multiclamp $700 \mathrm{~B}$ amplifier (Molecular Devices) with cells clamped at $-60 \mathrm{mV}$. Patch pipettes (resistance 5-10 M $\Omega$ ) were filled with internal recording solution containing the following (in mM): $100 \mathrm{~K}$-gluconate, $30 \mathrm{KCl}, 5 \mathrm{EGTA}$, and 10 HEPES, pH 7.3 (300 mOsm). Agonist and antagonist concentrations were as follows: $1 \mathrm{~mm}$ acetylcholine, $100 \mu \mathrm{m}$ glutamate, $10 \mathrm{~nm}$ MLA, $5 \mu \mathrm{M} \mathrm{DH} \beta \mathrm{E}$, and $10 \mu \mathrm{M}$ PNU. For mEPSCs, recordings were made from cells $>14$ DIV at 72-96 h following transfection. Events were recorded for 5-10 min (minimum of 300 events) from neurons clamped at -70 $\mathrm{mV}$. For all data analysis, currents were digitized at $10 \mathrm{kHz}$ and filtered at $2 \mathrm{kHz}$. Whole-cell currents were analyzed using pClamp 10.4 (Molecular Devices), and mEPSCs were analyzed using Mini Analysis (Synaptosoft). mEPSCs were manually selected with a minimum amplitude threshold of $6 \mathrm{pA}$ ( $\sim 3$ times the baseline noise level).

\section{Results}

\section{Specific Ly6 proteins modulate $\alpha 7 \mathrm{nAChR}$ function}

We used a combination of RT-PCR and bioinformatics to clone full-length cDNAs encoding 9 Ly6 genes from mouse brain or from ESTs derived from mouse brain. One of these cDNAs encoded Lynx2, which is known to accelerate desensitization and increase the effective concentration of agonist required to activate $\alpha 4 \beta 2 \mathrm{nAChRs}$ (Ibañez-Tallon et al., 2002). The other eight cDNAs encoded Ly6 proteins that have not previously been shown to modulate $\mathrm{nAChR}$ function. These included Ly6a, Ly6c1, Ly6c2, Ly6e, Ly6g6d, Ly6g6e, Ly6h, and Lypd2. Sequence alignments of these nine proteins (after removal of predicted signal peptides and C-terminal cleaved domains) reveal a clear conservation of the cysteine-rich motif thought to give rise to the classic "three-finger" domain found in snake venom $\alpha$-neurotoxins (Fig. 1).

To determine whether the proteins encoded by these cDNAs could alter $\alpha 7 \mathrm{nAChR}$ signaling, we adapted an established assay for calcium-conducting ionotropic receptor function (Yamauchi et al., 2011). In this assay, we cotransfected HEKtsa cells with cDNAs encoding $\alpha 7$ receptors and the calcium-sensitive ratiometric FRET reporter TN-XXL. $\alpha 7$ nAChRs are highly permeable to calcium. Thus, the FRET signal approximates $\alpha 7$ receptor activation as a function of agonist concentration, averaged over thousands of transfected cells per well. However, $\alpha 7 \mathrm{nAChRs}$ also desensitize within several hundred milliseconds (Quick and Lester, 2002; Wooltorton et al., 2003), which is much faster than the sampling rate of our flux assay $\left(\sim 4 \mathrm{~s}^{-1}\right)$. To overcome this problem, we blocked receptor desensitization with the positive allosteric modulator PNU-120596 for $30 \mathrm{~min}$ before measuring calcium fluxes (Yamauchi et al., 2011). Thus, our assay is limited to measuring steady-state levels of receptor activation and cannot report on kinetic changes. Nonetheless, we found that under control conditions stimulation of $\alpha 7 \mathrm{nAChRs}$ with increasing concentrations of nicotine produced a FRET concentration-response curve with an $\mathrm{EC}_{50}$ of $214 \pm 5 \mathrm{nM}$ (Fig. $2 \mathrm{~A}, \mathrm{C}$ ), which is similar to values reported for desensitizing receptors measured electrophysiologically (Badio and Daly, 1994; Gerzanich et al., 1995).

Next we asked how the presence of Ly6 molecules could alter $\alpha 7$ nAChR pharmacology. Interestingly, as observed with $\alpha 4 \beta 2$ nAChRs, coexpression of $\alpha 7 \mathrm{nAChRs}$ with Lynx 2 resulted in a significant increase in $\mathrm{EC}_{50}$ for nicotine (Ibañez-Tallon et al., 2002). Unexpectedly, however, Lynx2 also suppressed the maximum FRET response of $\alpha 7 \mathrm{nAChRs}$ by nearly $50 \%$, an effect that was also observed with Ly6h (Fig. $2 A, B$ ). Weaker but qualitatively similar effects on $\mathrm{EC}_{50}$, maximum response or both were also observed when $\alpha 7$ receptors were coexpressed with Ly6e, Ly6g6d, and Lypd2. Effects appeared to be independent of choice 
A

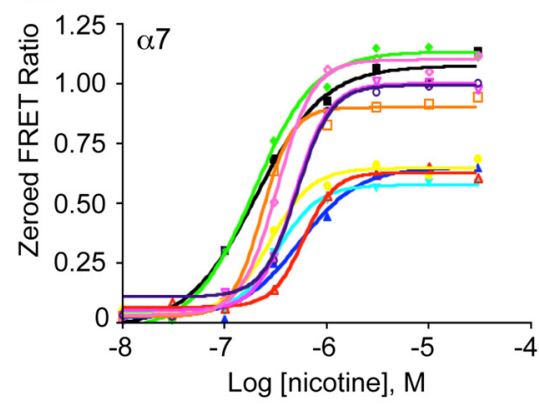

D
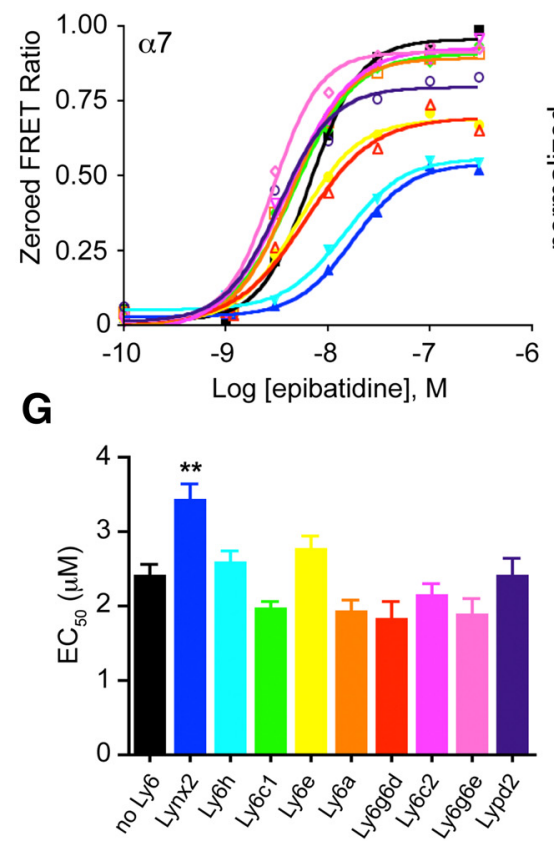

B

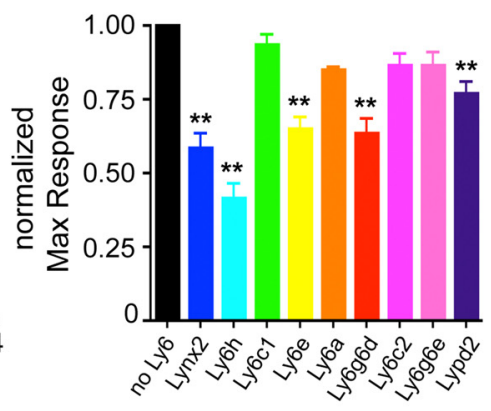

$\mathbf{E}$

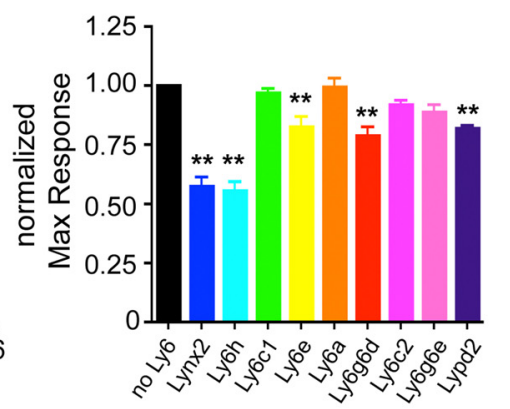

C

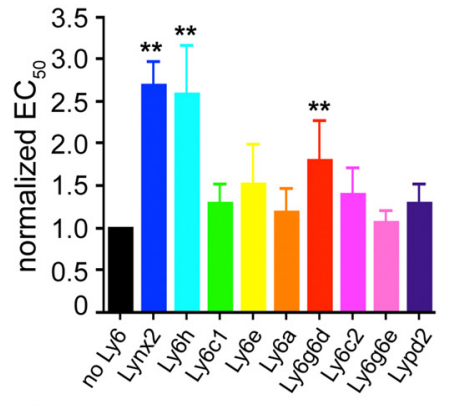

$\mathbf{F}$

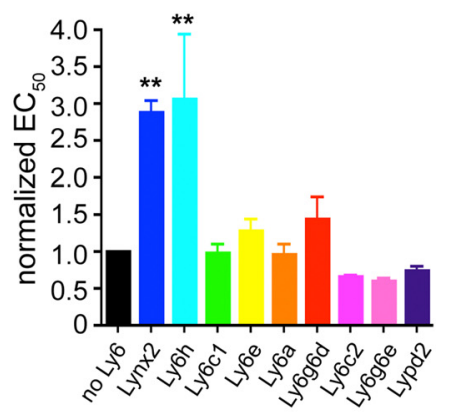

Figure 2. Ly6 proteins modulate $\alpha 7 \mathrm{nAChR}$ activity. Representative concentration-response curves for activation of $\alpha 7 \mathrm{nAChRs}$ by nicotine $(\boldsymbol{A})$ or epibatidine (D) in the absence (black line) or presence of various Ly6 genes (colored lines) in transiently transfected HEKtsa cells. Average maximum response to nicotine $(\boldsymbol{B})$ or epibatidine $(\boldsymbol{E})$ in the presence or Ly6 genes (colored bars) normalized to the control no Ly6 condition (black bars; $N=8$ ). Average $\mathrm{EC}_{50}$ for nicotine $(\boldsymbol{C}$ or epibatidine $(\boldsymbol{F})$ in the presence or Ly6 genes (colored bars) normalized to the control no Ly6 condition (black bars; $N=8) . G$, Average $\mathrm{EC}_{50}$ for PNU when treated with saturating $(30 \mu \mathrm{m})$ nicotine $\left(N>6 ;{ }^{* *} p<0.01\right.$ by one-way ANOVA with Dunnett's multiple-comparison post-test). Error bars indicate SEM.

of agonist since relative changes in receptor pharmacology were reproducible in nicotine and epibatidine (Fig. $2 A-F$ ).

One possible explanation for the reduction in maximum FRET response is that the relevant Ly6 proteins are competing with the positive allosteric modulator PNU, thus allowing desensitization to occur, which would lead to an underestimation of peak receptor activity. To test for this possibility, we held agonist concentration constant and varied the concentration of PNU in which cells were pre-incubated. We found that most Ly6 proteins did not alter the concentration-response curves for $\alpha 7 \mathrm{nAChRs}$ in the presence of PNU (Fig. 2G). The only exception was Lynx2, which caused a small but significant increase in $\mathrm{EC}_{50}$. This result suggests that the reduction in maximum response we observed in Figure 2 is likely to be caused mostly by a reduction in receptor activity at the cell surface rather than a displacement of PNU and a change in desensitization kinetics in our flux assay.

\section{Ly6 proteins form stable complexes with $\alpha 7$-subunits and} regulate levels of $\mathrm{nAChRs}$ at the cell surface

If Ly6 proteins were able to reduce activity of $\alpha 7 \mathrm{nAChRs}$ directly, then one might expect that modulator and receptor could form stable complexes, as has been demonstrated with Lynx1 and Lynx2 (Ibañez-Tallon et al., 2002; Tekinay et al., 2009). To test this hypothesis, we tagged Ly6 proteins at their C terminus with a MYC epitope and coexpressed them in transiently transfected HEKtsa cells with YFP-tagged $\alpha 7 \mathrm{nAChRs,} \mathrm{which} \mathrm{have} \mathrm{previously}$ been shown to form functional receptors (Murray et al., 2009). Western blot analysis following immunoprecipitation of YFP- $\alpha 7$ from these lysates revealed that all Ly6 proteins that altered nAChR pharmacology in our flux assay could be coimmunoprecipitated with $\alpha 7$-subunits (Fig. 3A). Although we cannot rule out the possibility that an as yet unidentified molecule acts as a bridge linking receptor to modulator, our results are consistent with a direct role for Ly6 proteins in modulating $\alpha 7 \mathrm{nAChR}$ activity.

Next we asked how Ly6 proteins could mediate a reduction in the maximum response of $\alpha 7 \mathrm{nAChRs}$ in our assay. To determine whether Ly6 proteins facilitate intracellular retention of $\alpha 7$ nAChRs, we first biotinylated the surfaces of HEKtsa cells that had been transfected with YFP- $\alpha 7$ cDNA alone or in combination with the Ly 6 clones that altered $\alpha 7$ concentration-response curves. We then lysed cells, immunoprecipitated biotinylated 
A

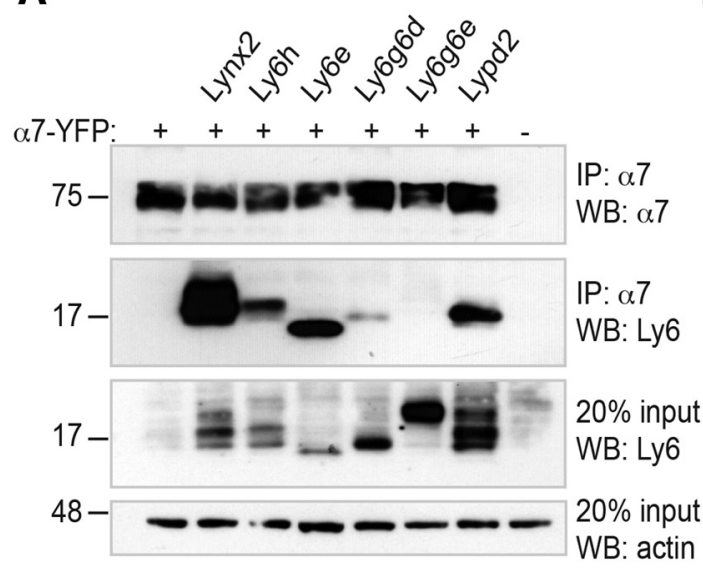

B

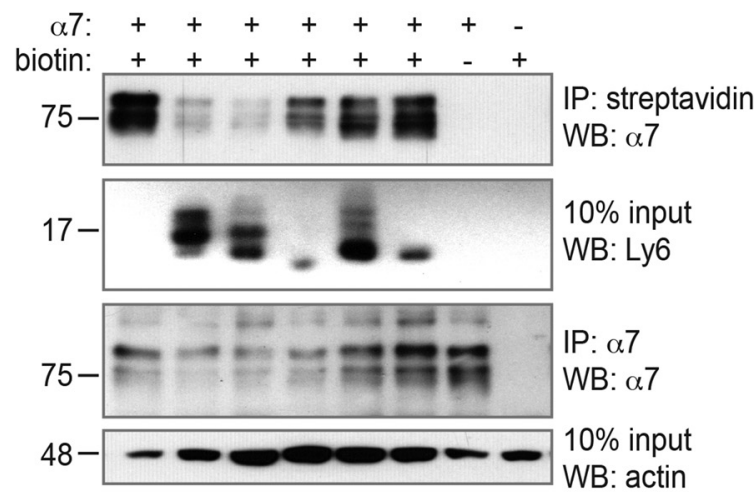

$\mathbf{E}$
C

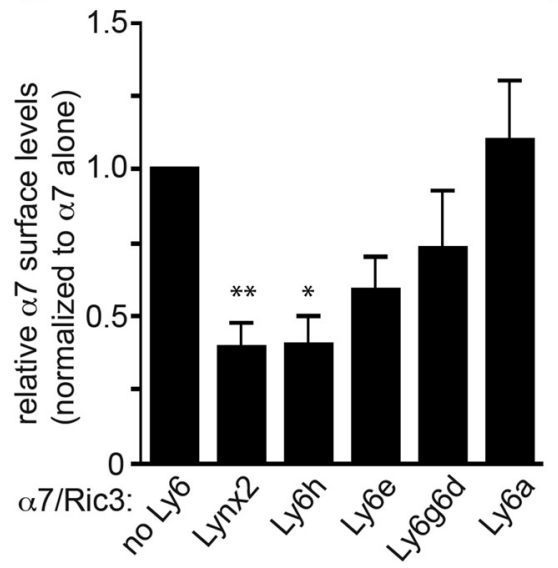

D

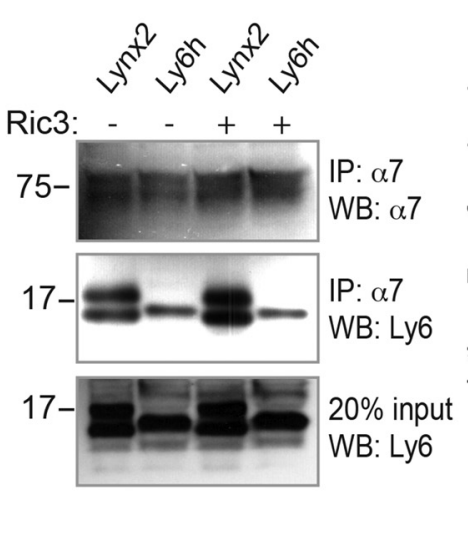

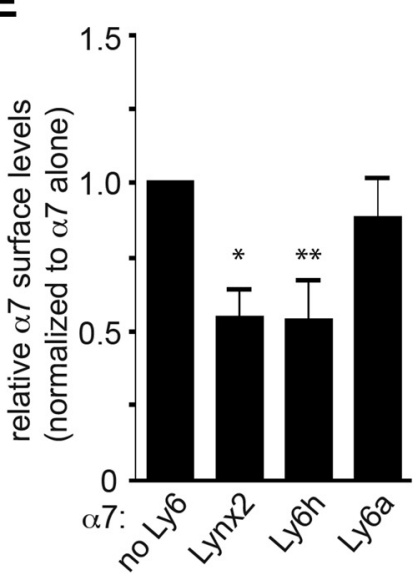

Figure 3. Ly6 proteins form stable complexes with $\alpha 7 \mathrm{nAChRs}$ and reduce expression of $\alpha 7 \mathrm{nAChRs}$ at the plasma membrane. A, Cotransfected Myc-tagged Ly6 proteins coimmunoprecipitate with YFP-tagged $\alpha 7$ in transiently transfected HEKtsa cells. Top, Immunoprecipitation (IP) with anti-GFP followed by Western blotting (WB) with anti-GFP. Upper middle, Immunoprecipitation with anti-GFP followed by Western blotting with anti-Myc. Lower middle, 20\% input total cell lysates Western blotted with anti-Myc. Bottom, 20\% input total cell lysates Western blotted with anti-actin as loading control. $\boldsymbol{B}$, Representative immunoblots of streptavidin immunoprecipitations of surface biotinylated $\alpha 7$ in transiently transfected HEKtsa cells. Top, Streptavidin immunoprecipitation followed by Western blotting with anti-GFP to detect surface $\alpha 7$. Upper middle, 10\% input total cell lysates Western blotted with anti-Myc to detect Ly6 protein expression. Lower middle, Anti-GFP immunoprecipitation followed by Western blotting with anti-GFP to detect total $\alpha 7$ levels. Bottom, 10\% input total cell lysates Western blotted with anti-actin as loading control. C, Average $\alpha 7$ surface protein quantified by measured pixel density of streptavidin-immunoprecipitated receptor normalized to total receptor immunoprecipitation $(N=8)$. D, Lynx2 and Ly6h can coimmunoprecipitate with $\alpha 7$ in the absence of transfected Ric3. E, Lynx2 and Ly6h reduce $\alpha 7$ surface levels in the absence of Ric3 $\left(N=10 ;{ }^{*} p<0.5,{ }^{* *} p<0.01\right.$ by one-way ANOVA with Dunnett's multiple-comparison test). Error bars indicate SEM.

surface proteins with streptavidin, and Western blotted to quantify levels of $\alpha$. In parallel we immunoprecipitated and Western blotted for changes in total cellular $\alpha 7$ from the same samples. We found that in contrast to total levels of $\alpha 7$, which were unchanged between conditions (Fig. 3A), $\alpha 7$ at the cell surface was reduced in the presence of the same Ly6 proteins that reduced $\alpha 7$ maximal response, and approximately to the same degree. This effect was significant for Lynx2 and Ly6h but was also trending for Ly6e and Ly6g6d (Fig. 3B,C). In contrast, coexpression of Ly6a, which had no functional effect on $\alpha 7$ activity in our FRET assay (Fig. $2 A, B, D, E$ ), also had no effect on $\alpha 7$ levels at the cell surface (Fig. $3 B, C$ ). These results strongly suggest that Lynx2, Ly6h, Ly6e, and Ly6g6d decrease the maximal response of $\alpha 7$ nAChRs to agonist by regulating intracellular trafficking of receptors.

Since our assays were performed with cotransfected Ric3, a known chaperone of $\alpha 7 \mathrm{nAChRs}$ (Halevi et al., 2002; Castillo et al., 2005), we asked whether Ric3 is required for association with and intracellular trafficking of receptors by Ly6 proteins. To address this question we repeated coimmunoprecipitation and sur- face biotinylation assays in the absence of Ric3. We found that the efficiency of complex formation between $\alpha 7$ and either Lynx 2 or Ly6h was unaffected (Fig. 3D). We also found that Ric3 had no effect on the ability of Lynx2 and Ly6h to reduce surface biotinylation of $\alpha 7$-subunits (Fig. 3E). Collectively, these data suggest that Ly6-dependent inhibition of $\alpha 7$ surface expression does not require displacement of Ric 3 and thus a reduction in chaperoning of nAChRs. However, we cannot exclude the possibility that Ric3 displacement might contribute to additional inhibition of $\alpha 7$.

Ly6h is necessary and sufficient to inhibit $\alpha 7 \mathrm{nAChR}$ activity in hippocampal pyramidal neurons

Since Ly6h has not been previously identified as a regulator of nAChR activity, we examined its role in neuronal function. First, we prepared hippocampal and cortical neurons from neonatal rats and performed RT-PCR on mRNA isolated from these cells at 7 DIV as well as from freshly dissected midbrain from P2 rat pups. We detected amplification products for both Ly6h as well as Lynx2 in all three brain regions (Fig. $4 A$ ), consistent with previ- 

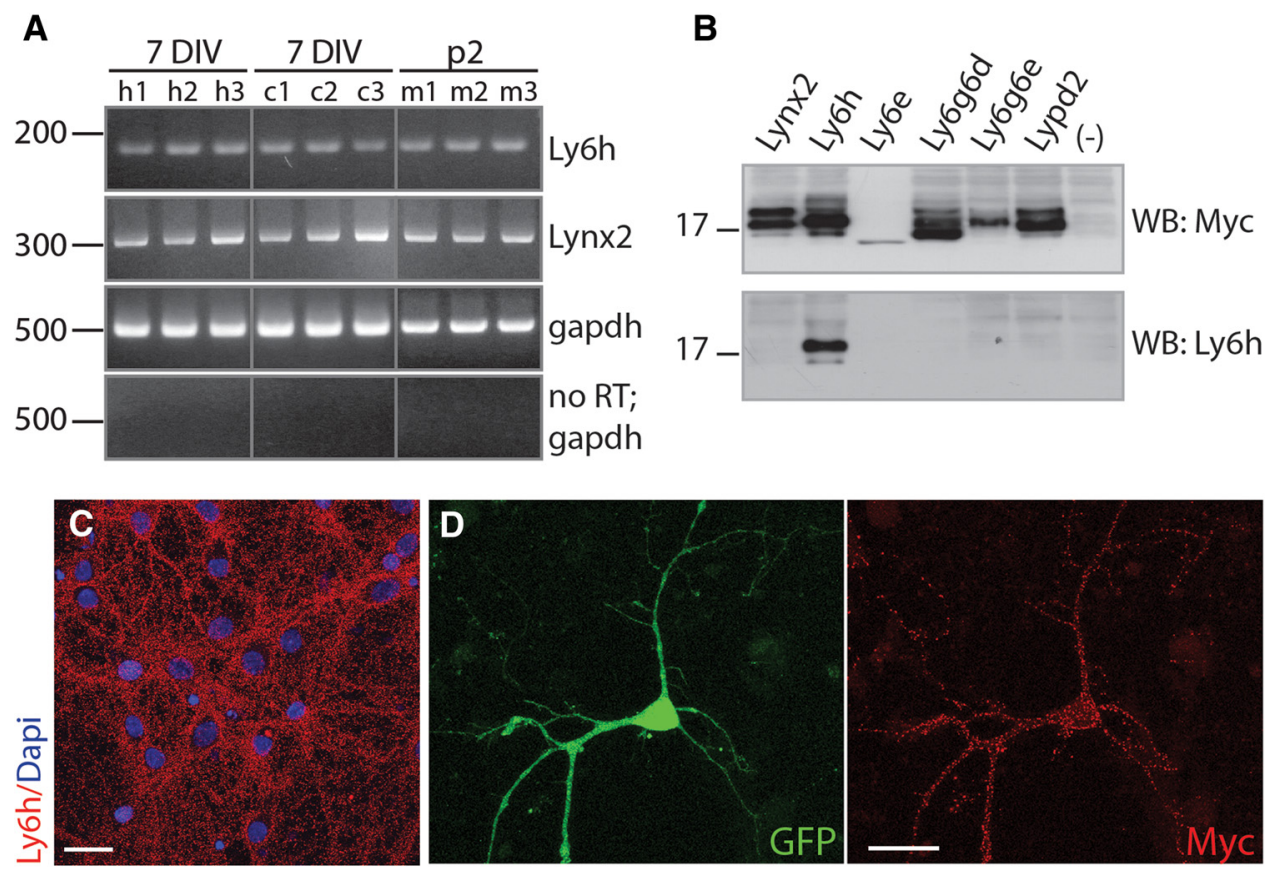

E

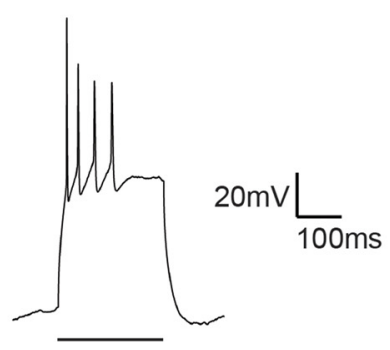

G

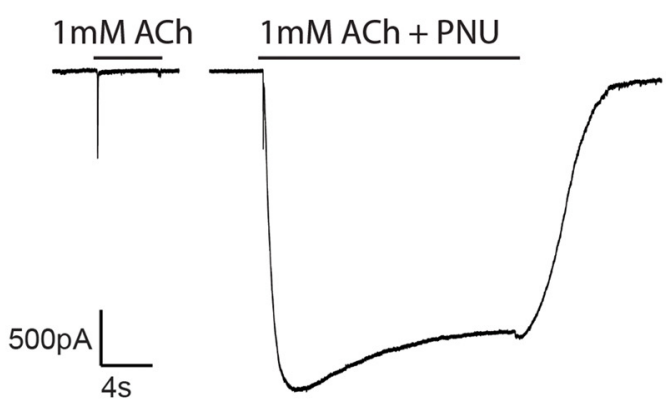

$\mathbf{F}$

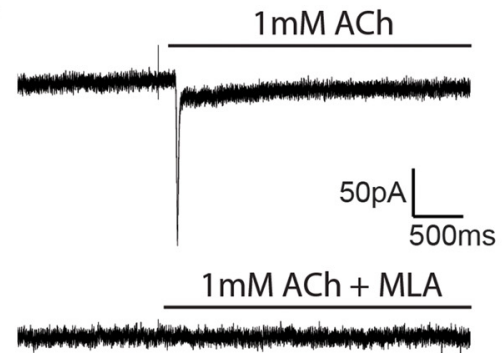

H

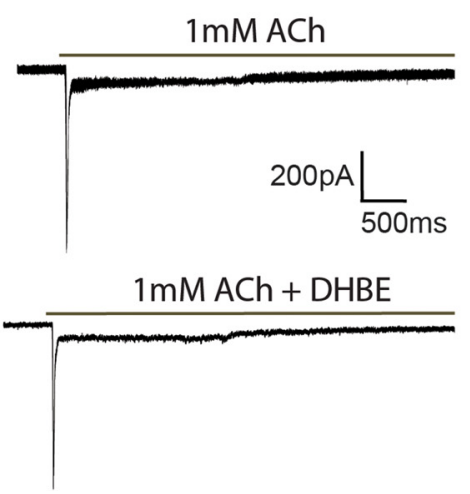

Figure 4. Primary cultured hippocampal pyramidal neurons express Ly6h and $\alpha 7$ currents. A, Ly6h and Lynx2 mRNAs are detectable by RT-PCR from 7 DIV primary hippocampal neurons (h1, h2, and $\mathrm{h} 3$ ) and cortical neurons ( $\mathrm{C}, \mathrm{C}$, and $\mathrm{C}$ ) and dissected P2 midbrain tissue. Gapdh was used as both a loading control (gapdh) and a negative control for genomic contamination (no RT; gapdh). $\boldsymbol{B}$, Representative immunoblot of various Ly6 proteins blotted with anti-Ly6h antibody. Only Ly6h (middle, lane 2) is recognized by this antibody. Top, Immunoblot anti-Myc for total expression. Bottom, Anti-actin blot for loading control. C, Representative immunostaining of primary hippocampal neurons (8 DIV) stained with DAPI (blue) and antibody against Ly6h (red). Scale bar, $25 \mu \mathrm{m}$. D, Immunostained pyramidal neuron transfected with GFP (green) and Myc-tagged Ly6h (red). Scale bar, $25 \mu \mathrm{m}$. $\boldsymbol{E}$, Cultured hippocampal neurons with a pyramidal morphology exhibit spike-frequency adaptation and display prominent afterhyperpolarization upon depolarizing current injection (solid bar below trace indicates $40 \mathrm{pA}$ current injection). $\boldsymbol{F}, \boldsymbol{H}$, ACh-evoked currents in hippocampal pyramidal neurons are blocked by MLA $(\boldsymbol{F})$ and potentiated by PNU $(\boldsymbol{G})$ but are unaffected by the $\alpha 4$-selective antagonist DHBE $(\boldsymbol{H})$.

ous reports (Thomsen et al., 2014). We then examined Ly6h protein expression in primary cultured hippocampal neurons by immunofluorescence confocal microscopy. We found that most neurons express Ly6h protein ubiquitously, though not necessarily uniformly, as puncta were frequently apparent (Fig. 4C). Our antibody appears to be selective since it only recognized Ly6h in Western blots of HEKtsa cells transfected with various Ly6 cDNAs (Fig. 4B).

The widespread expression of Ly6h suggests that this molecule might have a fundamental function within the hippocampus. To determine whether such a function involves regulation of $\alpha 7$ receptors, we recorded whole-cell nicotinic currents from primary 
A

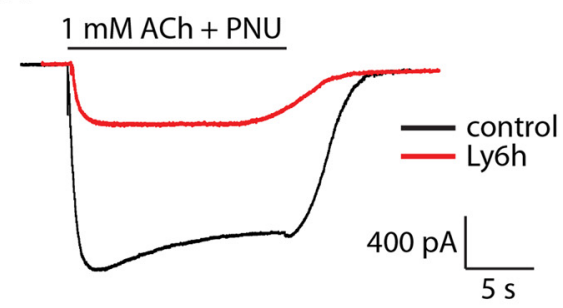

D

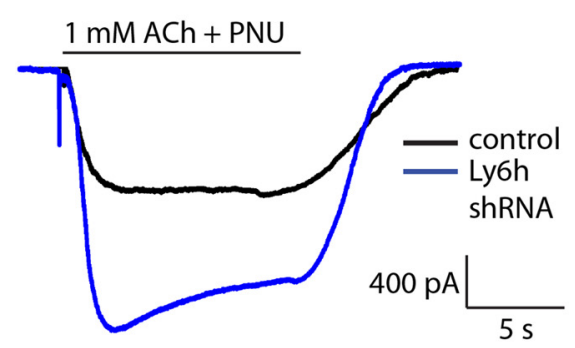

B

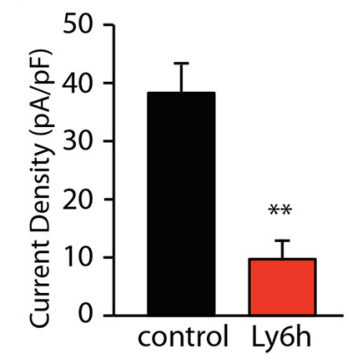

E

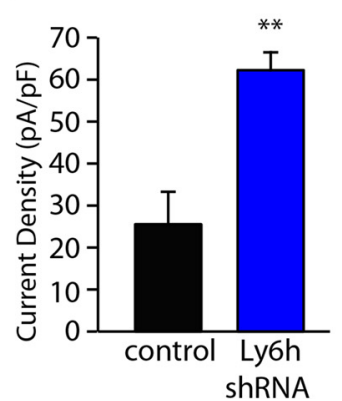

C

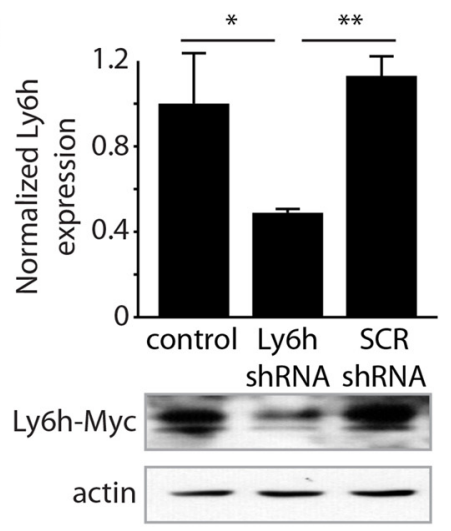

$\mathbf{F}$

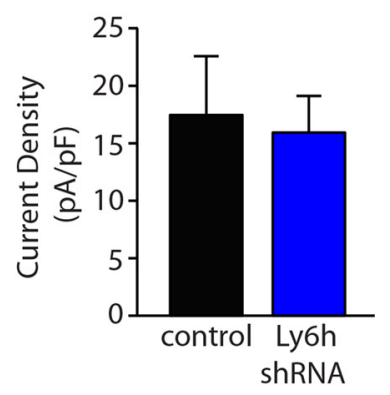

Figure 5. Ly6h suppresses $\alpha 7$ currents in primary hippocampal pyramidal neurons. $\boldsymbol{A}$, Representative ACh-evoked currents from neurons transfected with Ly6h (red trace) versus vector control (black trace). B, Quantification of recordings from multiple cells reveals a $40 \%$ decrease in current density in neurons overexpressing Ly6h ( $N=6-8$; ${ }^{* *} p<0.01$ by $t$ test). C, Ly6h shRNA reduces overexpressed Ly6h protein by $50 \%$. Top, Quantification of pixel density from immunoblots of total cell lysates from transiently transfected $\mathrm{HEK}$ tsa cells coexpressing Myc-tagged Ly6h (control; $N=$ 3) and shRNAs against Ly6h $(N=5)$ versus scrambled control ( $S C R ; N=3)$. Bottom, Representative immunoblot. ${ }^{*} p<0.05,{ }^{* *} p<0.01$ by one-way ANOVA with Tukey's multiple-comparison test. $\boldsymbol{D}$, Representative ACh-evoked currents from neurons transfected with shRNA (blue trace) versus scrambled control (black trace). $\boldsymbol{E}$, Quantification of neuronal recordings reveals a 100\% increase in current density following shRNA knockdown of Ly6h ( $N=8,9 ;{ }^{* *} p<0.01$ by $t$ test). $\boldsymbol{F}$, Glutamate-evoked currents in hippocampal pyramidal neurons are unaffected by transfection with Ly6h shRNA relative to scrambled control $(N=7,9)$.

cultured pyramidal neurons. We verified the identity of these neurons in several ways. First, we recorded from GFP-transfected cells matching the distinct morphology of pyramidal neurons (Fig. 4D). Second, we recorded action potentials under currentclamp conditions and confirmed the characteristic firing patterns of pyramidal neurons (Fig. 4E; Liu et al., 2013).

Over $90 \%$ of neurons that we recorded from met these criteria, and of these cells, $>95 \%$ expressed detectable levels of $\alpha 7$ currents, as assessed in four ways. First, application of $1 \mathrm{~mm} \mathrm{ACh}$ onto a neuron during a recording session elicited a current with rapid activation (peak $=11 \pm 0.4 \mathrm{~ms}$ from onset of current) and desensitization kinetics (tau $=9 \pm 0.6 \mathrm{~ms}$; Fig. $4 F, G$ ). Second, this current could be completely blocked by the $\alpha 7$-selective inhibitor methyllycaconitine (10 nM MLA; Fig. 4F). Third, the current could be potentiated by the $\alpha 7$-selective positive allosteric modulator PNU-120596 (Fig. 4G). Finally, the $\alpha 4$-selective antagonist dihydro- $\beta$-erythroidine (DHBE) had no effect on this current (Fig. 4H).

Having established that the vast majority of our primary cultured hippocampal cells were pyramidal neurons that expressed Ly6h protein and $\alpha 7$ currents, we then asked how Ly6h affects $\alpha 7$ function in these neurons. Based on our finding that Ly6h can suppress expression of $\alpha 7$ at the surface of HEKtsa cells (Fig. 3), we hypothesized that elevation of Ly6h expression would reduce $\alpha 7$ currents in hippocampal pyramidal neurons. To test this idea, we transfected primary cultured hippocampal neurons with cDNA encoding Ly6h and recorded endogenous $\alpha 7$ currents. Consistent with our hypothesis, we observed an $\sim 75 \%$ reduction in $\alpha 7$-mediated current in pyramidal neurons overexpressing Ly6h (Fig. $5 A, B$ ).

We also tested whether reducing Ly6h expression could have the opposite effect, i.e., disinhibition of $\alpha 7$ currents. To test this hypothesis we first generated an shRNA against Ly6h. This shRNA appeared to be functional since in transfected HEKtsa cells it reduced levels of MYC-tagged Ly6h by nearly $60 \%$ relative to scrambled control (Fig. 5C). Consistent with a role for Ly6h in suppressing $\alpha 7$ function, we found that shRNA knockdown of Ly6h enhanced $\alpha 7$ currents by $>100 \%$ relative to control conditions in hippocampal pyramidal neurons (Fig. $5 D, E$ ). Importantly, glutamate-evoked currents were unchanged by Ly6h knockdown (Fig. $5 F$ ), suggesting that Ly6h does not grossly affect overall pyramidal neuronal physiology but may selectively antagonize nAChR function. Collectively, these results suggest that Ly6h is both sufficient and necessary to limit $\alpha 7$ signaling cell autonomously in hippocampal neurons.

\section{Reducing Ly6h expression potentiates nicotine-mediated plasticity}

Nicotinic signaling can drive rewiring of neural circuitry during different periods of development (Muir-Robinson et al., 2002; Grubb et al., 2003; Morishita et al., 2010; Lozada et al., 2012b). How this reorganization occurs is unknown, but nicotine itself can stimulate $\alpha 7$-dependent glutamatergic synaptogenesis at drug concentrations close to those achieved during smoking. Although presynaptic $\alpha 7$ nAChRs probably contribute significantly to this process, recent evidence suggests that postsynaptic $\alpha 7$ recep- 
A control Ly6h shRNA nicotine

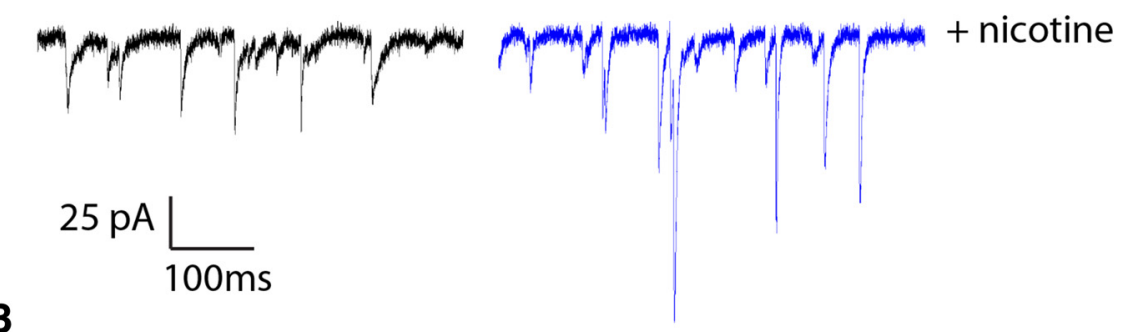

B
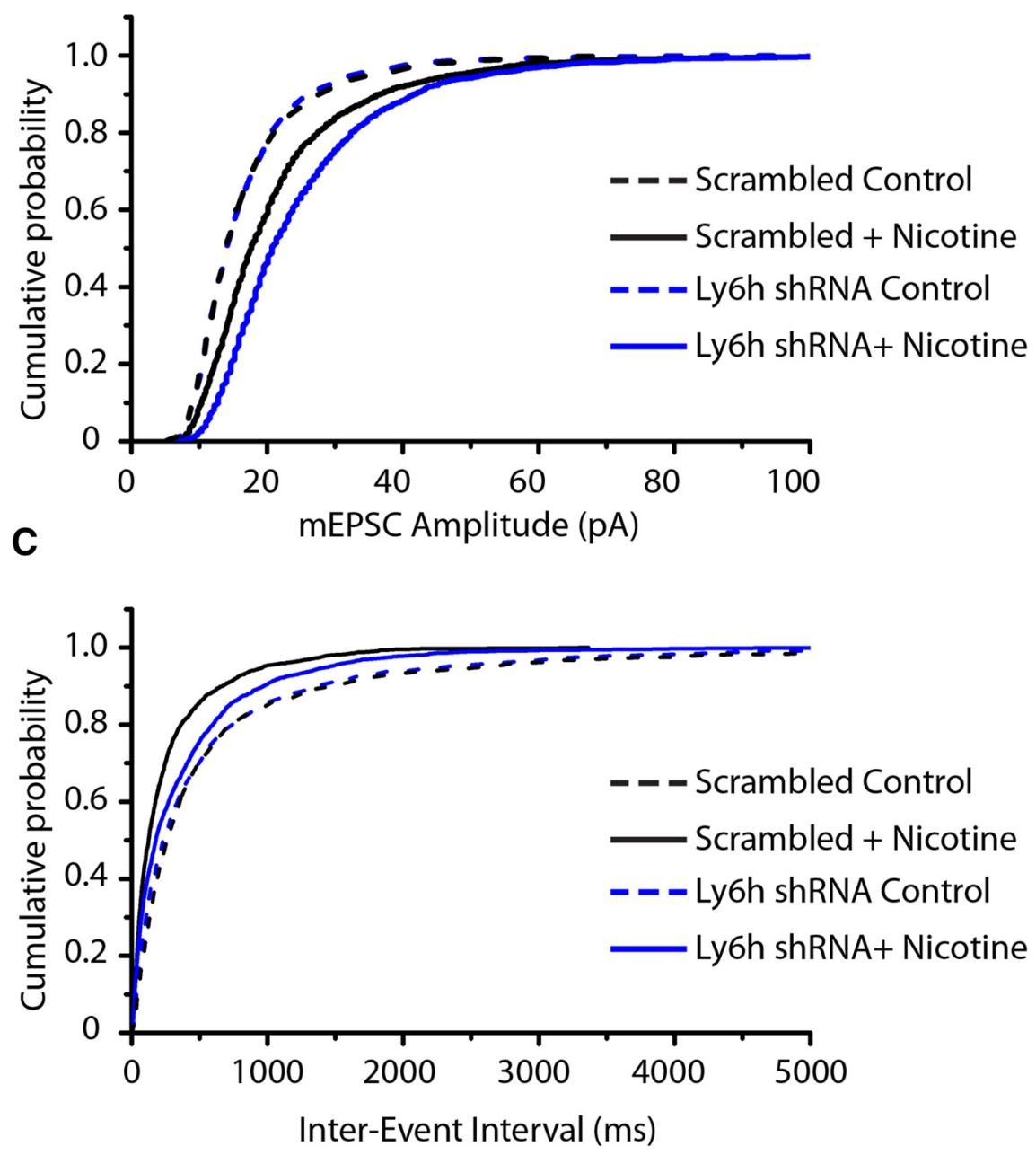

Figure 6. Ly6h modulates nicotine-dependent potentiation of glutamatergic signaling in primary cultured hippocampal pyramidal neurons. $A$, Representative mEPSCs from cultured hippocampal neurons ( $>14$ DIV) transfected with either Ly6h shRNA or scrambled control, and treated for $1-2 \mathrm{~h}$ with 0 versus $1 \mu \mathrm{m}$ nicotine before recording. $\boldsymbol{B}$, Cumulative probability plots of mEPSC amplitude following 0 or $1 \mu \mathrm{m}$ nicotine pretreatment, with or without knockdown of Ly6h. In the absence of nicotine pretreatment there is no difference between cells transfected with Ly6h shRNA versus scrambled control ( $N=5-6$ cells; $>1400$ events; $p>0.05$ by Kolmogorov-Smirnov test). In the presence of nicotine, however, $m E P S C$ amplitude is increased in both groups but to a larger degree in neurons transfected with Ly6h shRNA ( $N=8$ cells for each condition; $>2000$ events; $p<7.7 \times 10^{-8}$ by Kolmogorov-Smirnov test for nicotine + Ly6h shRNA vs nicotine + scrambled control). C, Cumulative probability plots for interevent intervals (IEls) of $\mathrm{mEPSC}$ in $\boldsymbol{B}$ show no difference in mEPSC frequency between cells transfected with Ly6h shRNA versus scrambled control in the absence of nicotine $(N=$ $5-6$ cells; $>1400$ events). After nicotine pretreatment, IEls are reduced in both shRNA-expressing and scrambled controlexpressing cells, with a less potent effect in the former group ( $N=8$ cells for each condition; $>2000$ events; $p<3.1305$ $10^{-16}$ by Kolmogorov-Smirnov test for nicotine + Ly6h shRNA vs nicotine + scrambled control). tors also play a role. For example, treatment of hippocampal neurons with nicotine for 2 h causes $\alpha 7$-dependent cell-autonomous AMPA receptor stabilization in postsynaptic membranes and a resulting increase in spontaneous glutamatergic mEPSCs (Halff et al., 2014). Since we have shown that knockdown of Ly6h enhances $\alpha 7$ currents, we hypothesized that knockdown of Ly6h should thus also enhance spontaneous glutamatergic mEPSCs.

To determine whether regulation of postsynaptic $\alpha 7$ currents by endogenous Ly6h acts as a gain control for glutamatergic signaling, we measured mEPSCs in cultured hippocampal neurons transfected with Ly6h shRNA or scrambled control. Tetrodotoxin (300 nM) was included in the bath solution to block action potential firing. We examined mEPSCs in particular because they enable analysis of single spontaneous events at individual synapses. Under control conditions the amplitude and frequency of these events are most likely controlled by a limited number of factors: the number of synapses, the number of receptors at each synapse, and the frequency of presynaptic spontaneous neurotransmitter release. Since we recorded from sparsely transfected neurons, we could isolate the effects of Ly6h knockdown on the postsynaptic cells from which we recorded. We sampled across all cells equally and we found 2.9-8.1 times more variance in mEPSC amplitude within a cell than between cells in each group, suggesting that pooling data from multiple cells did not introduce any significant error to our measurements (Kopec et al., 2007). We then used the Kolmogorov-Smirnov test to look for differences between cumulative distributions. Under basal conditions, mEPSC amplitude and frequency were unaffected by knockdown of Ly6h (Fig. $6 A-C)$, consistent with our previous observation that Ly6h does not modify glutamate-evoked currents (Fig. 5F).

To determine whether Ly6h could contribute to synaptic changes that may accompany chronic exposure to nicotine, we next treated cultured neurons for $1-2 \mathrm{~h}$ with $1 \mu \mathrm{M}$ nicotine. Notably, this concentration is within the range found within the serum of cigarette smokers (Matta et al., 2007). Similar to previous reports (Halff et al., 2014), mEPSC amplitude increased under our experimental conditions (Fig. $6 A, B)$. Interestingly, however, this increase was significantly greater in neurons transfected with Ly6h shRNA relative to scrambled control (Fig. 6A,B). Our data are thus consistent with studies that show that $\alpha 7$ signaling potentiates postsynaptic 
AMPA receptor currents (Halff et al., 2014). Our data also suggest that Ly6h is an integral regulator of this process, probably by determining how much $\alpha 7$ is available for activation.

Previous biochemical and electrophysiological analyses have suggested that nicotine also upregulates the number of functional synapses within the hippocampus (Halff et al., 2014; Damborsky et al., 2015). Consistent with such an interpretation, we observed an increase in frequency of mEPSCs in cultured hippocampal neurons treated for $1-2 \mathrm{~h}$ with $1 \mu \mathrm{M}$ nicotine (Fig. $6 \mathrm{C}$ ). This effect has largely been attributed to activation of presynaptic $\alpha 7$ receptors (Gray et al., 1996; Halff et al., 2014). Surprisingly, however, we observed a weaker increase in frequency of mEPSCs when Ly6h was knocked down (Fig. $6 C$ ), suggesting that postsynaptic $\alpha 7$ receptors may have a more prominent role in regulating glutamatergic synapse formation or stability than previously appreciated.

\section{Discussion}

Cholinergic nuclei in the brainstem and basal forebrain send diffuse projections throughout the brain (for review, see Dani and Bertrand, 2007). Through these projections acetylcholine acts as a global modulator of neuronal signaling. At presynaptic and postsynaptic targets, tight regulation of nAChRs is essential for maintaining normal brain function, including processes thought to contribute to learning and memory, attention, the sleep/wake cycle, and critical periods for developmental plasticity (Picciotto et al., 1995; Levin et al., 1998; Matsuyama and Matsumoto, 2003; Léna et al., 2004; Thiel and Fink, 2008; Morishita et al., 2010; Miwa et al., 2012; Medeiros et al., 2014; Wu et al., 2014). This regulation is accomplished in part by auxiliary proteins such as Lynx1 and Lynx2 (Miwa et al., 2006, 2012; Tekinay et al., 2009; Morishita et al., 2010), which accelerate desensitization and reduce affinity of heteromeric nAChRs for agonist. These properties have led some researchers to refer to Lynx1 and Lynx2 as "cholinergic brakes" (Morishita et al., 2010; Miwa et al., 2011). Indeed, knock-outs of Lynxl show signs of increased nicotinic signaling, including enhanced postsynaptic responses to nicotine and elevated levels of intracellular calcium in neurons (Morishita et al., 2010; Miwa et al., 2012). Restraining cholinergic signaling is important for organismal function and viability since Lynx1 knock-out mice also exhibit altered visual cortical plasticity and increased neurodegeneration (Miwa et al., 2006, 2012; Morishita et al., 2010).

Regulation of nAChRs appears to be a conserved property of Ly6 proteins since invertebrate homologs of Lynx1 and Lynx2 also suppress nAChR currents (Choo et al., 2008; Liu et al., 2009; Wu et al., 2014). However, nAChRs may not be the only regulatory targets of Ly6 proteins. For example, in Drosophila the SLEEPLESS protein increases levels and gating kinetics of voltage-gated K-channels in addition to antagonizing nAChRs (Koh et al., 2008; Wu et al., 2010, 2014; Dean et al., 2011). In mammals, however, only heteromeric nAChRs have been definitively implicated as regulatory targets of Ly6 proteins in neurons, and only Lynx 1 and Lynx 2 have been shown to form complexes with receptors. In this study, we focused on modulation of $\alpha 7$ nAChRs because of the roles these receptors have been proposed to play in forms of synaptic plasticity and cognition. These functions may be due to the relatively high permeability of $\alpha 7$ receptors to calcium, which distinguishes them from heteromeric nAChRs. This property allowed us to rapidly assay the effects of nine previously characterized and uncharacterized Ly6 proteins on $\alpha 7$ pharmacology using a FRET-based calcium flux assay. The obvious limitation of this assay is that sampling frequency is slow, which prevented us from easily measuring modulation of receptor kinetics. Thus, we may have missed subtle influences of different Ly6 proteins that would be more apparent by direct electrophysiological measurements. However, our flux assay still allowed us to measure modulation of steady-state receptor activity by blocking desensitization with the $\alpha 7$-selective positive allosteric modulator PNU. As a result we were able to identify four novel suppressors of $\alpha 7$ function.

There are several obvious potential mechanisms to explain such an effect. Ly6 proteins could reduce maximum open probability, single-channel conductance, relative calcium permeability, or cell-surface levels of $\alpha 7 \mathrm{nAChRs.} \mathrm{However,} \mathrm{we} \mathrm{also} \mathrm{note}$ the existence of a trend toward maximum response and $\mathrm{EC}_{50}$ being shifted together, with Ly6 proteins having either a strong or a weak effect on both measurements. Although these results look like classic noncompetitive inhibition, our surface biotinylation experiments suggest that this explanation is insufficient to explain our data, at least for Lynx2 and Ly6h. Instead, we found that these proteins reduced $\alpha 7$ levels at the plasma membrane. Thus, we propose that Lynx2 and Ly6h reduce $\alpha 7$ signaling at least in part by restricting the amount of activatable receptor at the cell surface. In this context, the rightward shifts in the concentrationresponse curves of $\alpha 7 \mathrm{nAChRs}$ in the presence of Lynx 2 and Ly6h seem likely to be attributable to competitive inhibition of residual receptor at the cell surface. These two mechanisms can largely explain our data.

With these ideas in mind, it is notable that nAChRs are "chaperonable" by nicotine, leading to export of receptors from the ER and increased levels at the plasma membrane (Kuryatov et al., 2005; Xiao et al., 2009; Richards et al., 2011; Srinivasan et al., 2011, 2012; Govind et al., 2012). Such an effect could result from displacement of endogenous molecules such as Ly6 proteins that might anchor or destabilize receptors in the ER (Govind et al., 2012; Srinivasan et al., 2012). If this hypothetical anchoring involved interactions with the receptor's orthosteric site then any residual protein complex that reached the cell surface should be sterically more resistant to activation by agonist. Although by definition a competitive antagonist should be overcome at saturating doses of agonist to restore the maximum response, this would not occur if the antagonistic interaction also led to a reduction in the number of receptors at the cell surface, as we observed. While competition between Lynx1/Lynx2 and agonist has been reported for heteromeric nAChRs (Ibañez-Tallon et al., 2002; Tekinay et al., 2009; Lyukmanova et al., 2011) and a recent report has shown that Lynx1 can alter the stoichiometry of heteromeric $\alpha 4 \beta 2$ receptors (Nichols et al., 2014), our results are the first report of trafficking effects of Ly6 proteins on any nAChRs.

Interest in $\alpha 7 \mathrm{nAChRs}$ has grown in recent years in particular because the amplitudes of currents mediated by these receptors have been shown to be regulated by amyloid $\beta$ protein, which has been implicated in Alzheimer's disease (Scerri et al., 2012; Posadas et al., 2013), especially in the hippocampus, which is thought to be impaired during the development of dementia (Selkoe, 2002; Palop et al., 2007). Other roles for $\alpha 7 \mathrm{nAChRs}$ include promoting glutamatergic synaptogenesis and rewiring of neuronal circuitry in response to chronic nicotine (Lozada et al., 2012a). Proteins that regulate $\alpha 7 \mathrm{nAChRs}$ may thus be important for normal neurophysiology and could in theory contribute to derangement of brain function under certain conditions.

Consistent with an important role for Ly6h in the brain, we detected transcript in cortex, hippocampus, and midbrain. Since these were the only regions of the nervous system that we tested, it is likely that Ly6h expresses even more broadly, as does $\alpha 7$. We 
focused on the hippocampus, where we detected Ly6h protein and $\alpha 7$ currents in nearly every neuron we examined. A functional relationship between these proteins became even clearer with our finding that bidirectional regulation of Ly6h expression has reciprocal effects on $\alpha 7$ currents in hippocampal neurons, with elevation of Ly6h inhibiting and reduction of Ly6h disinhibiting $\alpha 7$. This relationship was selective for nAChRs in that Ly6h knockdown enhanced ACh-evoked currents but had no effect on glutamate-evoked currents. Due to cross talk between nicotinic and glutamatergic signaling, however, this distinction is not necessarily expected to persist under all conditions. For example, $\alpha 7$ is required for plastic changes in neural circuitry, including nicotine-induced increases in functional glutamatergic synaptic connections among hippocampal neurons, an effect that is partly reflected by an increase in amplitude and frequency of mEPSCs. These effects have been attributed to calcium-mediated signaling through presynaptic $\alpha 7$, leading to increased mini frequency, and through postsynaptic $\alpha 7$, leading to increased stabilization of postsynaptic AMPA receptors and thus increased mini amplitude (Halff et al., 2014).

If expressed uniformly throughout our cultured neurons, Ly6h shRNA would be expected to enhance both effects. However, because our conditions led to sparsely transfected neurons, we were only able to knock down Ly6h in the postsynaptic cells from which we recorded. Under these conditions Ly6h knockdown would only be expected to enhance the amplitude effect of nicotine by increasing calcium current through $\alpha 7 \mathrm{nAChRs}$ at postsynaptic membranes. Indeed, when neurons were transfected with shRNA against Ly6h, the amplitudes of mEPSCs recorded after nicotine treatment were even greater than those that we observed with nicotine alone. It is unclear if, in this context, Ly6h controls the gain or the threshold for nicotine's effects on mEPSC amplitude. Unexpectedly, however, mEPSC frequency after nicotine treatment was actually reduced in shRNAtransfected cells. Since frequency of mEPSCs is attributable to both number of functional synapses and presynaptic release conditions, our results suggest that Ly6h may normally facilitate either unmasking of silent synapses or communication of a retrograde signal to presynaptic terminals to control frequency of neurotransmitter release. It is interesting to note in this context that mutations in genes encoding invertebrate homologs of Ly6h such as SLEEPLESS and TWIT increase mini frequency at the larval NMJ (Kim and Marqués, 2012). Thus, at least under certain conditions, one conserved function of many Ly6 molecules in the nervous system may be homeostatic control of synaptic glutamate signaling.

\section{References}

Badio B, Daly JW (1994) Epibatidine, a potent analgetic and nicotinic agonist. Mol Pharmacol 45:563-569. Medline

Castillo M, Mulet J, Gutiérrez LM, Ortiz JA, Castelán F, Gerber S, Sala S, Sala F, Criado M (2005) Dual role of the RIC-3 protein in trafficking of serotonin and nicotinic acetylcholine receptors. J Biol Chem 280:2706227068. CrossRef Medline

Chang KT, Berg DK (2001) Voltage-gated channels block nicotinic regulation of CREB phosphorylation and gene expression in neurons. Neuron 32:855-865. CrossRef Medline

Choo YM, Lee BH, Lee KS, Kim BY, Li J, Kim JG, Lee JH, Sohn HD, Nah SY, Jin BR (2008) Pr-lynx1, a modulator of nicotinic acetylcholine receptors in the insect. Mol Cell Neurosci 38:224-235. CrossRef Medline

Dajas-Bailador F, Wonnacott S (2004) Nicotinic acetylcholine receptors and the regulation of neuronal signalling. Trends Pharmacol Sci 25:317324. CrossRef Medline

Damborsky JC, Griffith WH, Winzer-Serhan UH (2015) Neonatal nicotine exposure increases excitatory synaptic transmission and attenuates nicotine-stimulated GABA release in the adult rat hippocampus. Neuropharmacology 88:187-198. CrossRef Medline

Dani JA, Bertrand D (2007) Nicotinic acetylcholine receptors and nicotinic cholinergic mechanisms of the central nervous system. Annu Rev Pharmacol Toxicol 47:699-729. CrossRef Medline

Dean T, Xu R, Joiner W, Sehgal A, Hoshi T (2011) Drosophila QVR/SSS Modulates the Activation and C-Type Inactivation Kinetics of Shaker K+ Channels. J Neurosci 31:11387-11395. CrossRef Medline

Dellisanti CD, Yao Y, Stroud JC, Wang ZZ, Chen L (2007) Crystal structure of the extracellular domain of nAChR alphal bound to alphabungarotoxin at 1.94 A resolution. Nat Neurosci 10:953-962. CrossRef Medline

Eisenhaber B, Bork P, Eisenhaber F (1999) Prediction of potential GPImodification sites in proprotein sequences. J Mol Biol 292:741-758. CrossRef Medline

Gerzanich V, Peng X, Wang F, Wells G, Anand R, Fletcher S, Lindstrom J (1995) Comparative pharmacology of epibatidine: a potent agonist for neuronal nicotinic acetylcholine receptors. Mol Pharmacol 48:774-782. Medline

Govind AP, Walsh H, Green WN (2012) Nicotine-induced upregulation of native neuronal nicotinic receptors is caused by multiple mechanisms. J Neurosci 32:2227-2238. CrossRef Medline

Gray R, Rajan AS, Radcliffe KA, Yakehiro M, Dani JA (1996) Hippocampal synaptic transmission enhanced by low concentrations of nicotine. Nature 383:713-716. CrossRef Medline

Grubb MS, Rossi FM, Changeux JP, Thompson ID (2003) Abnormal functional organization in the dorsal lateral geniculate nucleus of mice lacking the beta2 subunit of the nicotinic acetylcholine receptor. Neuron 40: 1161-1172. CrossRef Medline

Gu Z, Lamb PW, Yakel JL (2012) Cholinergic coordination of presynaptic and postsynaptic activity induces timing-dependent hippocampal synaptic plasticity. J Neurosci 32:12337-12348. CrossRef Medline

Halevi S, McKay J, Palfreyman M, Yassin L, Eshel M, Jorgensen E, Treinin M (2002) The C. elegans ric-3 gene is required for maturation of nicotinic acetylcholine receptors. EMBO J 21:1012-1020. CrossRef Medline

Halff AW, Gómez-Varela D, John D, Berg DK (2014) A novel mechanism for nicotinic potentiation of glutamatergic synapses. J Neurosci 34:20512064. CrossRef Medline

Ibañez-Tallon I, Miwa JM, Wang HL, Adams NC, Crabtree GW, Sine SM, Heintz N (2002) Novel modulation of neuronal nicotinic acetylcholine receptors by association with the endogenous prototoxin lynx1. Neuron 33:893-903. CrossRef Medline

Kim NC, Marqués G (2012) The Ly6 neurotoxin-like molecule target of wit (Twit) regulates spontaneous neurotransmitter release at the developing neuromuscular junction in Drosophila. Dev Neurobiol 72:1541-1558. CrossRef Medline

Koh K, Joiner WJ, Wu MN, Yue Z, Smith CJ, Sehgal A (2008) Identification of SLEEPLESS, a sleep-promoting factor. Science 321:372-376. CrossRef Medline

Kopec CD, Real E, Kessels HW, Malinow R (2007) GluR1 links structural and functional plasticity at excitatory synapses. J Neurosci 27:1370613718. CrossRef Medline

Kuryatov A, Luo J, Cooper J, Lindstrom J (2005) Nicotine acts as a pharmacological chaperone to up-regulate human alpha4beta2 acetylcholine receptors. Mol Pharmacol 68:1839-1851. Medline

Larkin MA, Blackshields G, Brown NP, Chenna R, McGettigan PA, McWilliam H, Valentin F, Wallace IM, Wilm A, Lopez R, Thompson JD, Gibson TJ, Higgins DG (2007) Clustal W and Clustal X version 2.0. Bioinformatics 23:2947-2948. CrossRef Medline

Léna C, Popa D, Grailhe R, Escourrou P, Changeux JP, Adrien J (2004) Beta2-containing nicotinic receptors contribute to the organization of sleep and regulate putative micro-arousals in mice. J Neurosci 24:57115718. CrossRef Medline

Levin ED, Bettegowda C, Weaver T, Christopher NC (1998) Nicotinedizocilpine interactions and working and reference memory performance of rats in the radial-arm maze. Pharmacol Biochem Behav 61:335-340. CrossRef Medline

Liu Q, Xie X, Lukas RJ, St John PA, Wu J (2013) A novel nicotinic mechanism underlies $\beta$-amyloid-induced neuronal hyperexcitation. J Neurosci 33:7253-7263. CrossRef Medline

Liu Z, Cao G, Li J, Bao H, Zhang Y (2009) Identification of two Lynx pro- 
teins in Nilaparvata lugens and the modulation on insect nicotinic acetylcholine receptors. J Neurochem 110:1707-1714. CrossRef Medline

Lozada AF, Wang X, Gounko NV, Massey KA, Duan J, Liu Z, Berg DK (2012a) Induction of Dendritic Spines by $\beta 2$-Containing Nicotinic Receptors. J Neurosci 32:8391-8400. CrossRef Medline

Lozada AF, Wang X, Gounko NV, Massey KA, Duan J, Liu Z, Berg DK (2012b) Glutamatergic synapse formation is promoted by $\alpha 7$-containing nicotinic acetylcholine receptors. J Neurosci 32:7651-7661. CrossRef Medline

Lyukmanova EN, Shenkarev ZO, Shulepko MA, Mineev KS, D’Hoedt D, Kasheverov IE, Filkin SY, Krivolapova AP, Janickova H, Dolezal V, Dolgikh DA, Arseniev AS, Bertrand D, Tsetlin VI, Kirpichnikov MP (2011) NMR structure and action on nicotinic acetylcholine receptors of watersoluble domain of human LYNX1. J Biol Chem 286:10618-10627. CrossRef Medline

Matsuyama S, Matsumoto A (2003) Epibatidine induces long-term potentiation (LTP) via activation of alpha4beta2 nicotinic acetylcholine receptors (nAChRs) in vivo in the intact mouse dentate gyrus: both alpha7 and alpha4beta2 nAChRs essential to nicotinic LTP. J Pharmacol Sci 93:180187. CrossRef Medline

Matta SG, Balfour DJ, Benowitz NL, Boyd RT, Buccafusco JJ, Caggiula AR, Craig CR, Collins AC, Damaj MI, Donny EC, Gardiner PS, Grady SR, Heberlein U, Leonard SS, Levin ED, Lukas RJ, Markou A, Marks MJ, McCallum SE, Parameswaran N, et al. (2007) Guidelines on nicotine dose selection for in vivo research. Psychopharmacology 190:269-319. CrossRef Medline

McGehee DS, Heath MJ, Gelber S, Devay P, Role LW (1995) Nicotine enhancement of fast excitatory synaptic transmission in CNS by presynaptic receptors. Science 269:1692-1696. CrossRef Medline

Medeiros R, Castello NA, Cheng D, Kitazawa M, Baglietto-Vargas D, Green KN, Esbenshade TA, Bitner RS, Decker MW, LaFerla FM (2014) $\alpha 7$ Nicotinic receptor agonist enhances cognition in aged 3xTg-AD mice with robust plaques and tangles. Am J Pathol 184:520-529. CrossRef Medline

Miwa JM, Stevens TR, King SL, Caldarone BJ, Ibanez-Tallon I, Xiao C, Fitzsimonds RM, Pavlides C, Lester HA, Picciotto MR, Heintz N (2006) The prototoxin lynx 1 acts on nicotinic acetylcholine receptors to balance neuronal activity and survival in vivo. Neuron 51:587-600. CrossRef Medline

Miwa JM, Freedman R, Lester HA (2011) Neural systems governed by nicotinic acetylcholine receptors: emerging hypotheses. Neuron 70:20-33. CrossRef Medline

Miwa JM, Lester HA, Walz A (2012) Optimizing cholinergic tone through lynx modulators of nicotinic receptors: implications for plasticity and nicotine addiction. Physiology 27:187-199. CrossRef Medline

Morishita H, Miwa JM, Heintz N, Hensch TK (2010) Lynx1, a cholinergic brake, limits plasticity in adult visual cortex. Science 330:1238-1240. CrossRef Medline

Muir-Robinson G, Hwang BJ, Feller MB (2002) Retinogeniculate axons undergo eye-specific segregation in the absence of eye-specific layers. J Neurosci 22:5259-5264. Medline

Murray TA, Liu Q, Whiteaker P, Wu J, Lukas RJ (2009) Nicotinic acetylcholine receptor alpha7 subunits with a C2 cytoplasmic loop yellow fluorescent protein insertion form functional receptors. Acta Pharmacol Sin 30:828-841. CrossRef Medline

Nichols WA, Henderson BJ, Yu C, Parker RL, Richards CI, Lester HA, Miwa JM (2014) Lynx1 shifts $\alpha 4 \beta 2$ nicotinic receptor subunit stoichiometry by affecting assembly in the endoplasmic reticulum. J Biol Chem 289: 31423-31432. CrossRef Medline

Palop JJ, Chin J, Roberson ED, Wang J, Thwin MT, Bien-Ly N, Yoo J, Ho KO, Yu GQ, Kreitzer A, Finkbeiner S, Noebels JL, Mucke L (2007) Aberrant excitatory neuronal activity and compensatory remodeling of inhibitory hippocampal circuits in mouse models of Alzheimer's disease. Neuron 55:697-711. CrossRef Medline

Petersen TN, Brunak S, von Heijne G, Nielsen H (2011) SignalP 4.0: discriminating signal peptides from transmembrane regions. Nat Methods 8:785-786. CrossRef Medline

Picciotto MR, Zoli M, Léna C, Bessis A, Lallemand Y, Le Novère N, Vincent P,
Pich EM, Brûlet P, Changeux JP (1995) Abnormal avoidance learning in mice lacking functional high-affinity nicotine receptor in the brain. $\mathrm{Na}$ ture 374:65-67. CrossRef Medline

Posadas I, López-Hernández B, Ceña V (2013) Nicotinic receptors in neurodegeneration. Curr Neuropharmacol 11:298-314. CrossRef Medline

Puddifoot C, Martel MA, Soriano FX, Camacho A, Vidal-Puig A, Wyllie DJ, Hardingham GE (2012) PGC- $1 \alpha$ negatively regulates extrasynaptic NMDAR activity and excitotoxicity. J Neurosci 32:6995-7000. CrossRef Medline

Quick MW, Lester RA (2002) Desensitization of neuronal nicotinic receptors. J Neurobiol 53:457-478. CrossRef Medline

Richards CI, Srinivasan R, Xiao C, Mackey ED, Miwa JM, Lester HA (2011) Trafficking of alpha $4^{*}$ nicotinic receptors revealed by superecliptic phluorin: effects of a beta 4 amyotrophic lateral sclerosis-associated mutation and chronic exposure to nicotine. J Biol Chem 286:31241-31249. CrossRef Medline

Scerri C, Stewart CA, Balfour DJ, Breen KC (2012) Nicotine modifies in vivo and in vitro rat hippocampal amyloid precursor protein processing in young but not old rats. Neurosci Lett 514:22-26. CrossRef Medline

Selkoe DJ (2002) Alzheimer's disease is a synaptic failure. Science 298:789_ 791. CrossRef Medline

Srinivasan R, Pantoja R, Moss FJ, Mackey ED, Son CD, Miwa J, Lester HA (2011) Nicotine up-regulates alpha4beta2 nicotinic receptors and ER exit sites via stoichiometry-dependent chaperoning. J Gen Physiol 137: 59-79. CrossRef Medline

Srinivasan R, Richards CI, Xiao C, Rhee D, Pantoja R, Dougherty DA, Miwa JM, Lester HA (2012) Pharmacological chaperoning of nicotinic acetylcholine receptors reduces the ER stress response. Mol Pharmacol 81:759_ 769. CrossRef Medline

Tekinay AB, Nong Y, Miwa JM, Lieberam I, Ibanez-Tallon I, Greengard P, Heintz N (2009) A role for LYNX2 in anxiety-related behavior. Proc Natl Acad Sci U S A 106:4477-4482. CrossRef Medline

Thiel CM, Fink GR (2008) Effects of the cholinergic agonist nicotine on reorienting of visual spatial attention and top-down attentional control. Neuroscience 152:381-390. CrossRef Medline

Thomsen MS, Cinar B, Jensen MM, Lyukmanova EN, Shulepko MA, Tsetlin V, Klein AB, Mikkelsen JD (2014) Expression of the Ly-6 family proteins Lynx1 and Ly6H in the rat brain is compartmentalized, cell-type specific, and developmentally regulated. Brain Struct Funct 219:1923-1934. CrossRef Medline

Wooltorton JR, Pidoplichko VI, Broide RS, Dani JA (2003) Differential desensitization and distribution of nicotinic acetylcholine receptor subtypes in midbrain dopamine areas. J Neurosci 23:3176-3185. Medline

Wu M, Li J, Engleka KA, Zhou B, Lu MM, Plotkin JB, Epstein JA (2008) Persistent expression of Pax 3 in the neural crest causes cleft palate and defective osteogenesis in mice. J Clin Invest 118:2076-2087. CrossRef Medline

Wu M, Robinson JE, Joiner WJ (2014) SLEEPLESS is a bifunctional regulator of excitability and cholinergic synaptic transmission. Curr Biol 24: 621-629. CrossRef Medline

Wu MN, Joiner WJ, Dean T, Yue Z, Smith CJ, Chen D, Hoshi T, Sehgal A, Koh K (2010) SLEEPLESS, a Ly-6/neurotoxin family member, regulates the levels, localization and activity of Shaker. Nat Neurosci 13:69-75. CrossRef Medline

Xiao C, Nashmi R, McKinney S, Cai H, McIntosh JM, Lester HA (2009) Chronic nicotine selectively enhances alpha4beta $2^{\star}$ nicotinic acetylcholine receptors in the nigrostriatal dopamine pathway. J Neurosci 29: 12428-12439. CrossRef Medline

Yamauchi JG, Nemecz Á, Nguyen QT, Muller A, Schroeder LF, Talley TT, Lindstrom J, Kleinfeld D, Taylor P (2011) Characterizing ligand-gated ion channel receptors with genetically encoded $\mathrm{Ca} 2{ }^{++}$sensors. PLoS One 6:e16519. CrossRef Medline

Yamazaki Y, Jia Y, Niu R, Sumikawa K (2006) Nicotine exposure in vivo induces long-lasting enhancement of NMDA receptor-mediated currents in the hippocampus. Eur J Neurosci 23:1819-1828. CrossRef Medline 